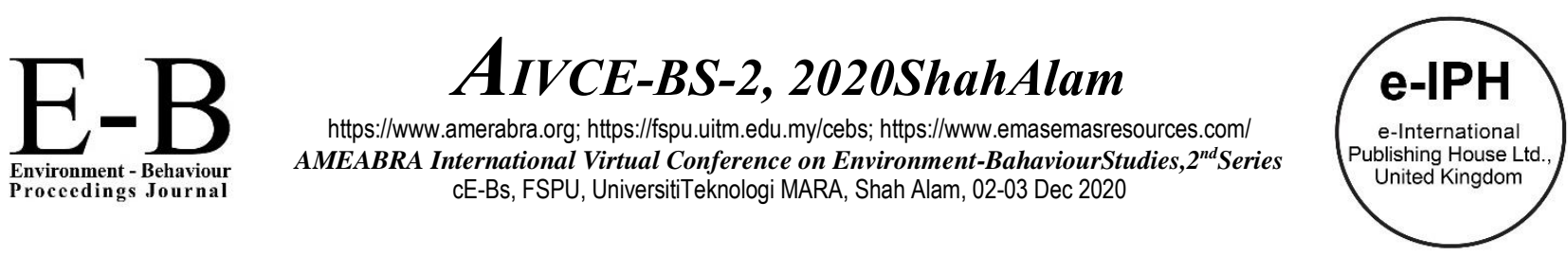

\title{
A Comparative Study of Landmark on Heritage Tourism in Sumatra
}

\author{
Nurlisa Ginting ${ }^{1}$, Nurinayat Vinky Rahman², Achmad Delianur Nasution ${ }^{1}$ \\ 1 Department of Architecture, Faculty of Engineering, \\ 2 Toba Lake \& Sustainable Tourism Working Group, \\ Universitas Sumatera Utara, 9 Dr. T. Mansur Street, Medan, 20155, Indonesia \\ nurlisa@usu.ac.id,n.vinky@usu.ac.id, a.delianur@usu.ac.id \\ Tel: +62811608102
}

\begin{abstract}
Landmark, as part of heritage tourism distinctiveness, has a critical role in enhancing the city identity to make it more attractive and more identified. Sumatera Island has heritage tourism with similar culture and history that can found in Medan, Bukittinggi, and Siak. This research was conducted to determine the comparison of the landmark on the similar heritage tourism in Sumatera. The third essential element of the landmark, i.e., iconic, contrast, and accessibility, was investigated using the mixed-method. This study shows that the monumental buildings and historical story formed as the landmark in those three historic tourist cities.
\end{abstract}

Keywords: Heritage tourism; place identity; distinctiveness; landmark

eISSN: 2398-42870 2020. The Authors. Published for AMER ABRA cE-Bs by e-International Publishing House, Ltd., UK. This is an open access article under the CC BYNC-ND license (http://creativecommons.org/licenses/by-nc-nd/4.0/). Peer-review under responsibility of AMER (Association of Malaysian Environment-Behaviour Researchers), ABRA (Association of Behavioural Researchers on Asians) and cE-Bs (Centre for Environment-Behaviour Studies), Faculty of Architecture, Planning \& Surveying, Universiti Teknologi MARA, Malaysia.

DOI: https://doi.org/10.21834/ebpj.v5i15.2491.

\subsection{Introduction}

The tourism sector is one of the country's largest sources of foreign exchange (UNWTO, 2012; Ginting 2016), especially in developing countries that focus on economic growth and regional development (Diniz, 2014). Indonesia is rich in historical and cultural heritage, which is reflected in local wisdom. In an urban context, a heritage city is a city in which there are historical traces of assets with authentic local wisdom. Heritage cities create a place identity (Ginting, 2016). Also, the values of local wisdom, which become the identity of the place are an attraction for heritage tourism (Ashworth, 2007). One that shapes the image and identity of a historical city is the landmark aspect (Hussain, 2018). Landmark usually be seen from a distance by observers and serve as a guide in finding the way. Heritage tourism is said to be a landmark if it is used as a place orientation/icon, different from the surrounding environment and has good accessibility.

Sumatra has great heritage tourism potential because of its cultural and historical diversity. Medan, Bukittinggi, and Siak have similar culture and history in Sumatra. It because visitors have difficulty distinguishing one heritage tourist destination from another. Therefore, the research aims to determine the comparison of landmarks on similar heritage tourism in Sumatra, i.e., Medan, Bukittinggi and Siak. These findings will show the differences in landmarks on similar heritage tourism in Sumatra so that they give an impression and influence someone's memory to be attracted to heritage tourism in Sumatra.

eISSN: 2398-4287C 2020. The Authors. Published for AMER ABRA cE-Bs by e-International Publishing House, Ltd., UK. This is an open access article under the CC BYNC-ND license (http://creativecommons.org/licenses/by-nc-nd/4.0/). Peer-review under responsibility of AMER (Association of Malaysian Environment-Behaviour Researchers), ABRA (Association of Behavioural Researchers on Asians) and cE-Bs (Centre for Environment-Behaviour Studies), Faculty of Architecture, Planning \& Surveying, Universiti Teknologi MARA, Malaysia.

DOI: https://doi.org/10.21834/ebpj.v5i15.2491. 


\subsection{Literature Review}

\subsection{Heritage tourism}

Heritage tourism is a type of tourism that unites educational activities, cultural, tourism and natural preservation as well as economic activities (Cahyadi, 2009). Heritage tourism is the type of tourism that is most in demand (Ginting \& Wahid, 2015). The integration of history and culture in heritage tourism can provide an experience of a place. The object of historical heritage is an attraction that makes heritage tourism an alternative to homogenise in world tourism (Ashworth, 2007). The main reason tourists visit a historical object is because of its quality, special programs offered, the architectural attractiveness of the historic building (Staiff, 1999), and historical value or historical area in a city. Cities that have the potential for heritage tourism will give satisfaction to tourists if the tourists can enjoy the uniqueness of existing heritage tourism objects and create emotional and psychological reactions between visitors and these objects (McCabe, 2004). For tourists, heritage tourism provides an experience of unique values that add to the impression of a place and attract them to come back to that place. Heritage is divided into two types, namely tangible heritage and intangible heritage (Timothy, 2003; Selmanovic et al., 2018). Tangible heritage is an inheritance that cannot be moved, such as buildings, statues, sites and the landscape of the area. Also, intangible heritage is a legacy that can be transferred, such as personal collections and literary products.

\subsection{Landmark}

One of the aspects that shape the image and identity of a historical city is a landmark (Hussain, 2018). Landmark is a vertical element that is used as an orientation or guide in finding a way (Lynch, 1960). It is visible from afar to the observer (Lynch, 1960). Therefore, markers are often used as identities and guides on a trip to a place. Landmarks grouped into local landmarks, constructed landmarks, natural landmarks and distant landmarks (Lynch, 1969), so it doesn't have to be vertical or three-dimensional objects. A landmark as a feature of a city landscape has physical uniqueness that gives an impression and affects a person's memory. The existence of a landmark in a place can also create distinctiveness because a landmark is a striking object that uses as a measuring point in an area (Hussain, 2018).

The characteristics of a landmark provide an image and influence a person's memory of the city. Landmark describes several attributes, including orientation/icon/point of reference, uniqueness/difference/contrast, symbolism and architectural values (Hussain, 2018). Landmarks are considered contrast when there are one or more significant differences between the object and the environment (Ginting, 2020). The contextuality between landmarks and the environment is also maintained to create a continuity of image and identity. Then, accessibility is also an indicator of landmarks. Good accessibility affects visitors to come (Ginting, 2016). In this study, the landmark is an element that used as the orientation of the place/icon as long as they are different from the surrounding environment and have good accessibility (Table 1).

Table 1 Aspects of Landmark

\begin{tabular}{|c|c|}
\hline Landmark & Indicator \\
\hline Icon/Place Orientation & Historic buildings, cultural heritage objects and cultural activities \\
\hline Contrast with Environment & $\begin{array}{l}\text { Building contrasts with the environment and building part of the city's } \\
\text { landmark }\end{array}$ \\
\hline Accessibility & Easy access, public transportation and pedestrian path \\
\hline
\end{tabular}

\subsection{Methodology}

\subsection{Research Area}

This research was conducted in Medan, Bukittinggi and Siak (Fig.1). The city is famous as a heritage tourism destination. There are various famous heritage tourist attractions in Medan, such as; Maimun Palace, Al Mahsun Grand Mosque, Sri Deli Park, Tjong A Fie's House, London Sumatra, the Old Post Office, Bank Indonesia and Medan City Hall. Maimun Palace, Al Mahsun Grand Mosque and Sri Deli Park are heritage buildings of the Deli Sultanate. The building design has a blend of Malay tradition, European and Islamic architecture. Meanwhile, London Sumatra, Post Office, Bank Indonesia, Medan City Hall and Tjong A Fie's House are heritage buildings from the Dutch colonial era.

In Bukittinggi, the famous heritage tourism is Pagaruyung Palace, Jam Gadang, Bung Hatta's Birth House, Fort de Kock and the Japanese Hole. Pagaruyung Palace is a relic of the Pagaruyung Kingdom. The Palace has the concept of the longhouse with a roof typical Minangkabau protruding like buffalo horns. Meanwhile, Jam Gadang is a gift from Queen Wilhelmina of the Netherlands. Then, there is Bung Hatta's Birth House, which is the birthplace of Indonesia's first vice president and spent his childhood. The town also has a historic fort Dutch heritage is Fort de Kock. It was built on a hill to observe the conditions around Bukittinggi. Also, in Bukittinggi, there is a Japanese heritage, namely the Japanese Hole. It was built underground for the benefit of the Japanese defence.

Then, the famous heritage attractions in Siak are Siak Sri Indrapura Palace, Kato Ship, Syahabudin Great Mosque and Tangsi Holland. Siak Sri Indrapura Palace, Kato Ship and Syahabudin Great Mosque are heritage buildings of the Siak Sultanate. Meanwhile, there is a Dutch heritage fort located beside the Siak river, namely Tangsi Holland. 


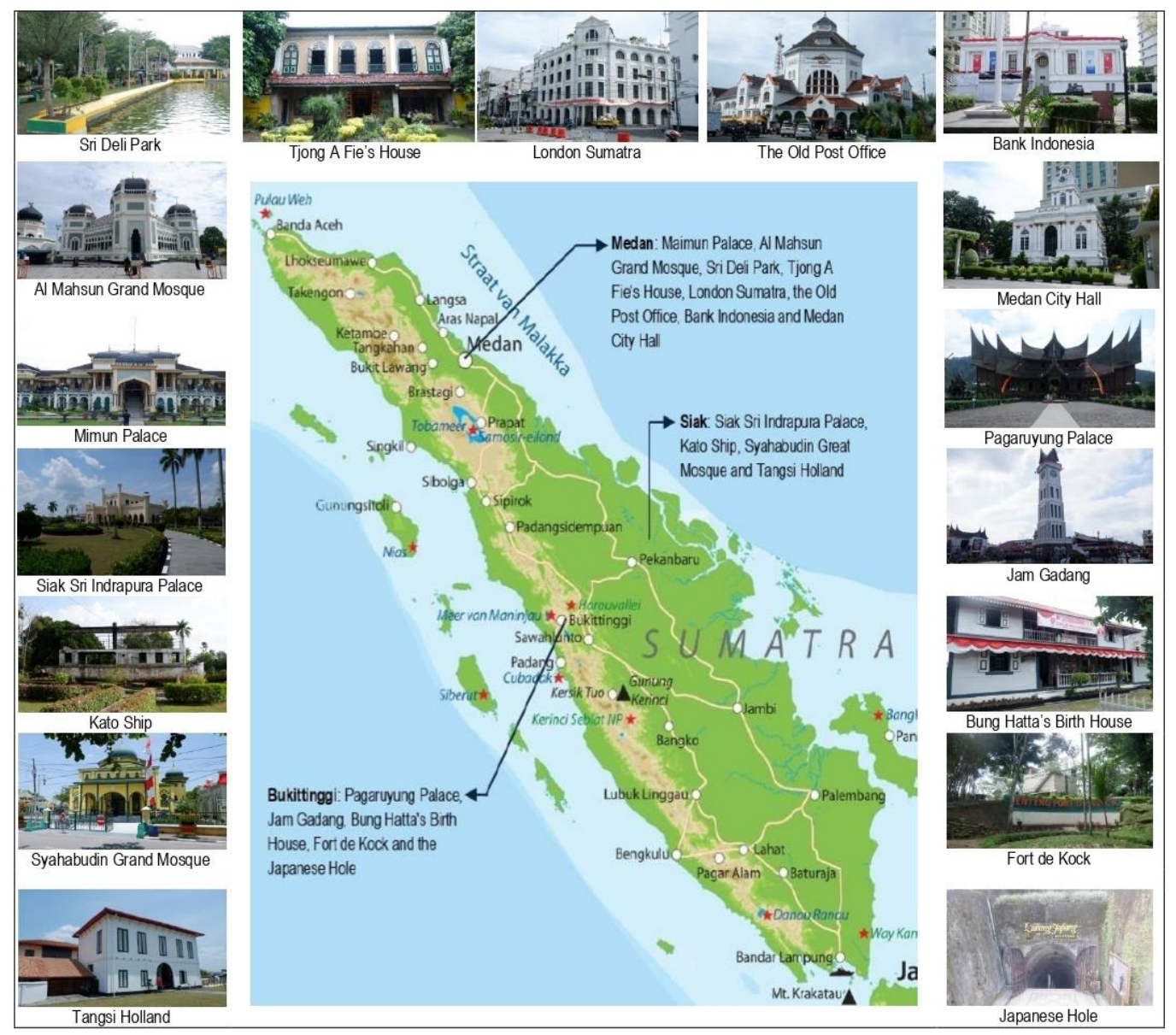

Fig. 1. Research Area (Source: Author)

\subsection{Methods}

This research uses a mixed-method, combining the aspects of Landmark by field observations, questionnaire distribution to 150 respondents, and depth interviews with 12 key respondents in Medan, Bukittinggi and Siak. The distribution of the questionnaire with the google application form was carried out via social media, Instagram, Facebook, Twitter, WhatsApp and E-mail. Also, conduct indepth interviews with key informants who are the government, institutions, academics and managers of heritage tourism destinations. Field observations carried out by collecting the physical characteristics of the building, activities, public facilities, access, pedestrians and other things needed. Then, researchers measured the questionnaire on a five-point scale ranging from strongly agree (5) to strongly disagree (1) for landmark aspects of heritage tourism. Landmark aspects of heritage tourism are analysed on indicators: icon/place orientation, contrast with environment and accessibility.

\subsection{Findings}

\subsection{Respondents}

This study involved 150 respondents consisting of 75 local people and 75 tourists who visited heritage tourism in Medan, Bukittinggi and Siak. Each city is represented by 50 respondents consisting of 25 local people and 25 tourists. As a result, the majority of respondents $64.67 \%$ were women $(n=97)$ and $35,33 \%$ were men $(n=53)$. The average respondents were $18-24$ years old $(48 \%)$, followed by $25-49$ years $(34,67 \%)$ and $50-65$ years $(17,33 \%)$. In this study, the majority of respondents with the latest education were Bachelor with 89 people $(59,33 \%), 43$ people Senior High School(28,67\%), 16 people Masters $(10,67 \%)$ and two people Doctor $(1,33 \%)$. Education between one individual and another is certainly not the same so that it instils a different mindset. Different mindsets can certainly influence a person's behaviour in making decisions.

\subsection{Landmark Aspect}

The heritage buildings and site in the Medan, Bukittinggi and Siak are representative of the city landmark. From the data tabulated, the study found that both local people and tourist had a positive perception of the tourism heritage from the landmark aspect. Table 2 shows the average score of 8 items from the landmark aspect. The question with the highest mean ratings is: "When I remember these places, I remember the historic buildings" (Table 2). It shows that respondents agree that a historical building can be an orientation/icon of a 
place. It shows that the monumental buildings formed as the landmark in those three historic tourist cities. Conversely, the provision of public facilities got the lowest score, especially in the ease of use of public transport and pedestrian path quality.

Table 2. The Average Value of The Landmark Aspects of Heritage Tourism

\begin{tabular}{|c|c|c|c|c|c|c|c|c|c|}
\hline \multirow{2}{*}{$\begin{array}{l}\text { Landmark } \\
\text { Aspect }\end{array}$} & \multicolumn{2}{|r|}{ Statements } & \multicolumn{2}{|c|}{ Medan } & \multicolumn{2}{|c|}{ Bukittinggi } & \multicolumn{2}{|c|}{ Siak } & \multirow{2}{*}{ Mean } \\
\hline & & & LP & $\mathrm{T}$ & LP & $\mathrm{T}$ & LP & $\mathrm{T}$ & \\
\hline \multirow{3}{*}{$\begin{array}{l}\text { Icon/Place } \\
\text { Orientation }\end{array}$} & L1 & $\begin{array}{l}\text { When I remember these places, I remember } \\
\text { the historic buildings }\end{array}$ & 4,28 & 4,52 & 4,40 & 4,28 & 4,64 & 4,32 & 4,41 \\
\hline & L2 & $\begin{array}{l}\text { When I remember these places, I remember } \\
\text { the cultural heritage objects (statues, paintings, } \\
\text { photographs, documents, etc.) }\end{array}$ & 3,60 & 4,00 & 3,68 & 3,60 & 4,32 & 3,60 & 3,80 \\
\hline & L3 & $\begin{array}{l}\text { When I remember these places, I remember } \\
\text { the cultural activities }\end{array}$ & 4,08 & 4,28 & 3,68 & 3,60 & 4,28 & 4,08 & 4,00 \\
\hline \multirow{2}{*}{$\begin{array}{l}\text { Contrast with } \\
\text { Environment }\end{array}$} & L4 & $\begin{array}{l}\text { The building /area contrasts with the } \\
\text { environment }\end{array}$ & 3,92 & 4,16 & 3,68 & 3,60 & 4,20 & 3,88 & 3,91 \\
\hline & L5 & $\begin{array}{l}\text { Buildings /areas are part of the city's } \\
\text { landmarks/ icons }\end{array}$ & 4,48 & 4,48 & 4,72 & 4,56 & 4,80 & 4,72 & 4,63 \\
\hline \multirow{3}{*}{ Accessibility } & L6 & This place is easy to access & 3,96 & 4,36 & 4,32 & 4,00 & 4,60 & 4,40 & 4,27 \\
\hline & L7 & $\begin{array}{l}\text { Easy to use public transportation to access the } \\
\text { area }\end{array}$ & 3,48 & 3,72 & 4,12 & 3,48 & 2,88 & 2,68 & 3,39 \\
\hline & $\mathrm{L} 8$ & There is a comfortable pedestrian path & 2,72 & 2,80 & 4,04 & 3,84 & 4,32 & 4,00 & 3,62 \\
\hline \multicolumn{3}{|c|}{$\begin{array}{c}\text { Value Format: } 5=\text { strongly agree } \& 1=\text { strongly disagree } \\
L P=\text { Local People, } T=\text { Tourist }\end{array}$} & 3,79 & 4,04 & 4,07 & 3,90 & 4,29 & 3,98 & 4,01 \\
\hline
\end{tabular}

\subsection{Discussion}

\subsection{Icon/Place Orientation}

Buildings or site which easy to see and identify is the basis of an icon of the city. While the icon of the city assigned as the landmark of the city. The landmark of the city plays a critical role in attracting tourist to travel. The uniqueness of the icon can form by the culture, history, activity, of the shape of the building in an area (Ginting et al., 2020). Comparing those three cities, we found that the Icon of the city came from the monumentality of heritage buildings (Fig.2). The Palaces building had the highest score as the representation of the icon of the city. Local people and tourists in Medan ( $L P=4,28 ; T=4,52)$, Bukittinggi $(L P=4,40 ; T=4,28)$, and $\operatorname{Siak}(L P=4,28 ; T=4,52)$ agreed that historic buildings remind them of the city.

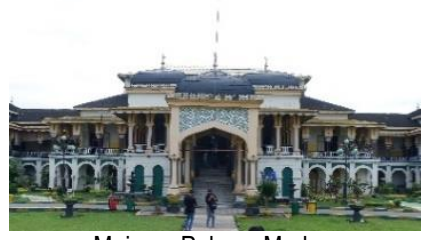

Maimun Palace, Medan

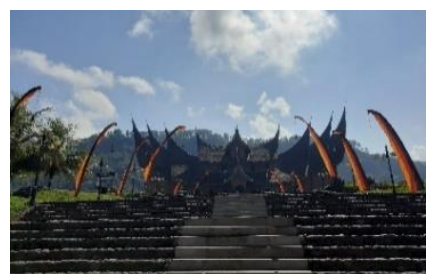

Pagaruyung Palace, Bukittinggi

Fig. 2. Icon of Heritage Tourism (Source: Author)

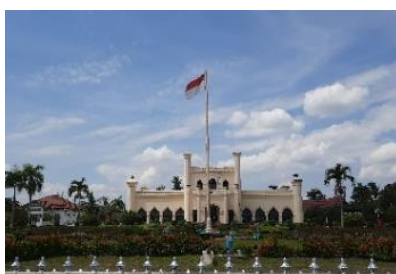

Siak Sri Indrapura Palace, Siak

Heritage tourism attracts the tourist's attention by offering a unique experience. The tangible and intangible assets provided in the heritage buildings and areas will give the typical character in the city. The aesthetic and educational aspects that come from the heritage buildings and sites can promote it as the icon of the city (Zakariya et al., 2020). Intangible aspect that support more the heritage building in Medan ( $L P=4,08 ; T=4,28)$, Bukittinggi ( $L P=3,68 ; T=3,60)$, and Siak $(L P=4,28 ; T=4,08)$ is the cultural activity than the cultural heritage object such as statues statues, paintings, photographs, documents, etc. Respondent perception about Bukittinggi has the lowest score about this statement when comparing with Respondent perception in Medan and Siak. This condition affected because of Istana Pagaruyung had a fire in 2007.

Then, the existence of cultural activities will increase tourists in heritage tourism areas. Local people and tourists in Medan (LP=4,28; $T=4,08)$, Bukittinggi $(L P=3,68 ; T=3,60)$, and Siak $(L P=4,28 ; T=4,08)$ agreed that cultural activities also remind them of the city. Cultural activities include festivals, parades and traditional dances. Festivals activities include the Serumpun Malay Title in Medan, the Minangkabau Traditional Silek Festival in Bukittinggi, Siak Bermadah Festival and International Cultural Parades in Siak. Festivals and parades are usually held once a year, except for traditional dances. The positive response of respondents to cultural tourism indicates that they are motivated to visit the festival, which significantly affects their satisfaction and intention to return. 


\subsection{Contrast with Environment}

The Royal Complex from the old Malay sultanates in general consists of the royal palace, mosques, mausoleums, and traditional kampongs. Tangible and intangible presence from the royal complex provides a significant character to form the heritage identity. The history of the king and the architecture styles create the building contrast with other surrounding building (Samsudin et al., 2018). Comparing the history of the kingdom between Medan, Bukittinggi, and Siak, it can say that the Pagaruyung Kingdom was the only one that didn't be the part of the Malay sultan's system. Even though this kingdom had a strong relationship with the Maimun Sultanates and Siak Sri Indrapura Sultanates, but Pagaruyung still not used the Malay sultan's system. Respondent perception about contrasty of the heritage site and buildings with the surround environment in Bukittingi $(L P=3,68 ; T=3,60)$ also has different than Medan $(L P=3,92 ; T=$ $4,16)$ and Siak ( $L P=4,20 ; T=3,88)$. Apart from the difference in the royal system found in the Pagaruyung palace, the existence of other buildings that have similar architectural forms around the palace such as Silinduang Bulan Palace makes that historical building not too contrasting with the surrounding environment (Fig. 3). In the other hand, Respondent agreed about the heritage site, and buildings in Medan and Siak is the contrast with the environment.

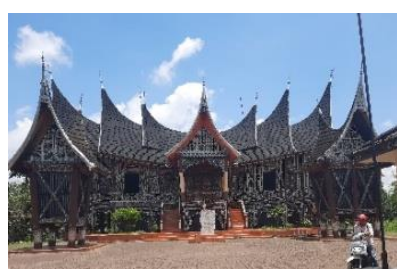

Silinduang Bulan Palace, Bukittinggi

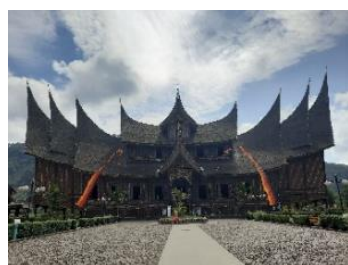

Pagaruyung Palace, Bukittinggi

Fig. 3. Buildings with Similar Architecture Style in Bukittinggi

(Source: Author)

The contrast of the heritage site and buildings with the surrounding environment didn't affect the role of those heritage building as the icon of the city. Respondent was strongly agree the heritage site and buildings in Medan ( $L P=4,48 ; T=4,48)$, Bukittinggi ( $L P=4,72$; $\mathrm{T}=4,56)$ and Siak ( $\mathrm{LP}=4,80 ; \mathrm{T}=4,72)$ become the part of the city landmark. Maimun Palace, Pagaruyung Palace, and Siak Sri Indrapura Palace were also used by the local government as an Icon while promoting the city's tourism. It also affects the tourist mindset to identify the city based on their palace. Heritage site not should be revitalised and preserved because of the form of the physical things only, but also because they save the history of the growth of the city. Turn the heritage site and buildings as the icon of the city needed to support it's potential as the tourist attraction. Promoting the heritage site will open the commercial opportunity to enhance the local community's quality of life (Spirou et al., 2020). The contrasty of the heritage site in Medan, Bukittinggi, and Siak wasn't only about the tangible things. Still, the intangible aspect, such as the history of the kingdoms in the past is also strengthening it as the icon of the city.

\subsection{Accessibility}

Accessibility is an indicator or parameter of landmark characteristics. Good accessibility and availability of public transport affect a person's positive perceptions of tourist destinations (Arasll, 2014). In this study, the assessment of accessibility from the ease of access, public transportation, road conditions and pedestrian paths in heritage tourist destinations. Accessibility can be interpreted as the comfort and ease of access to a destination or a place (Shi, 2008). In this study, local people and tourists give a positive assessment of the ease of accessing heritage tourism: Medan ( $L P=3,96 ; T=4,36)$, Bukittinggi $(L P=4,32 ; T=4,00)$ and Siak $(L P=4,60 ; T=4,40)$ (Table 2). According to local people and tourists, heritage tourism in Siak has better access than Medan and Bukittinggi. Vehicles and pedestrians can easily access heritage tourist destinations in Siak because of the wide and smooth road conditions. Heritage tourism in Medan and Bukittinggi also has wide roads, but if there are many visitors or there are problems on the highway, there will be quite a heavy traffic jam. Ease of access to destinations will affect individual interest in coming (Ginting, 2016). It also increases a person's interest in visiting.

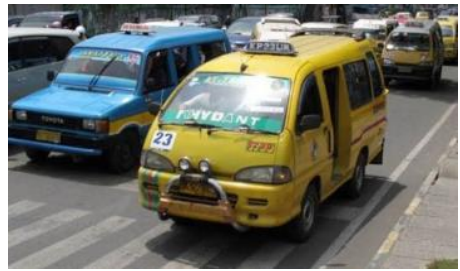

Public Transportation in Medan

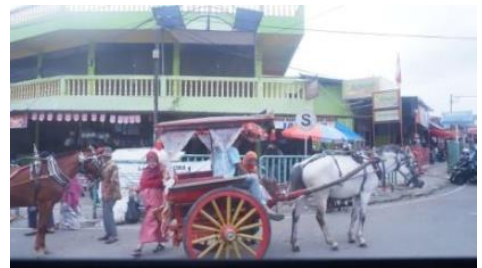

Public Transportation in Bukittinggi Fig. 4. Public Transportation (Source: Author)

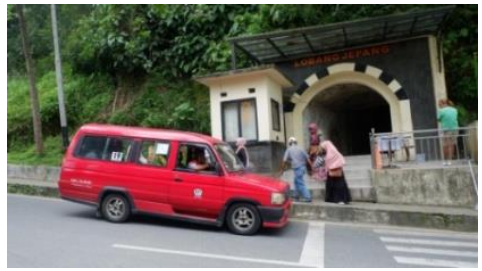

Public Transportation in Siak

Good public transportation plays an important role in reducing the use of private cars and improving the welfare of non-mobile households (Mavoa, 2012). Based on the survey results, local people and tourists give a positive assessment of the ease of using public transportation to heritage tourism in Medan ( $L P=3,48 ; T=3,72$ ) and Bukittinggi ( $L P=4,12 ; T=3,48)$ (Tabel 2). Meanwhile, for heritage tourism in Siak,they are difficult to use public transportation ( $L P=2,88 ; T=2,68)$. In Bukittinggi and Medan, visitors can easily find public transportation. However, stopping places for public transportation in Medan and Bukittinggi are difficult to find. Public transportation that can be used to reach the heritage tourist destinations of Medan and Bukittinggi are public transportation, motorcycle taxis, rickshaws 
and taxis. And there is unique transportation in Bukittinggi heritage tourism, namely the Bendi horse (Fig 4). Whereas in Siak, they also struggle to find public transportation, and there are no clear stops for public transport in Siak. The availability of public transportation and good accessibility in tourist destinations will affect perceptions.

Good pedestrian facilities facilitate visitor access to many destinations, such as short routes, well-marked and protected routes (Huang, 2012). Based on the survey results, the public and tourists give a positive assessment of pedestrian comfort towards heritage tourism in Bukittinggi $(L P=4,04 ; T=3,84)$ and Siak $(L P=4,32 ; T=4,00)$ (Table 2). Meanwhile, they feel uncomfortable walking on pedestrian heritage tourism in Medan ( $L P=2,72 ; T=2,80)$. It is because the pedestrian paths in heritage tourist destinations are hollow or uneven and often used as a motorcycle parking. The pedestrian path is also used illegally by traders. It makes visitors feel uncomfortable and unsafe when using the pedestrian path.

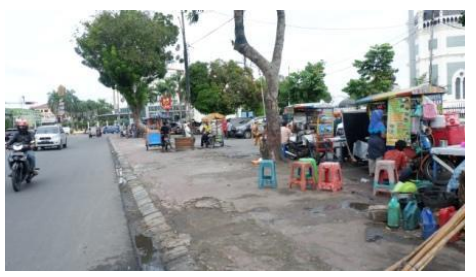

Pedestrian Path in Medan

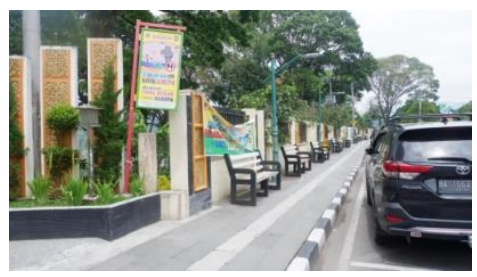

Pedestrian Path in Bukittinggi

Fig. 5. Pedestrian Path

(Source: Author)

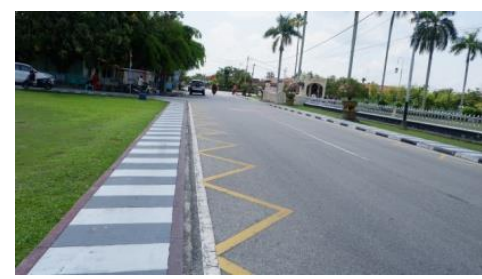

Pedestrian Path in Siak

\subsection{Conclusion \& Recommendations}

This study found that the royal palace is the most powerful icon in heritage tourism and has an influential role as a city landmark. The contrast of buildings is not only considered based on the tangible aspects of the heritage sites and buildings. Still, it is also very much influenced by the characters that emerge from its history. As happened in historical tourism in Bukittinggi, although the shape of the building is considered not too contrasting with the surrounding environment, the role of the building that keeps the history of the Minang tribe still encourages it to become an icon of the region. The ease of accessibility to heritage tourism areas also affects the existence of historical buildings and areas as part of city landmarks. This research is still limited to the landmark aspect, so further research is needed on other elements in supporting the diversity of historical tourism.

\section{Acknowledgement}

The authors wish to thank the Ministry of Research and Technology and the Higher Education Republic of Indonesia and Universitas Sumatera Utara for their invaluable support towards this study. The support is under the research grant DPRM of the Year 2020 Contract Number:139/UN5.2.3.1/PPM/KP-DPRM/2020.

\section{Paper Contribution to Related Field of Study}

This research contributes to the field of urban planning and tourism for the development of heritage tourism by applying the landmark theory in cities.

\section{References}

Araslı, H., \& Baradarani, S. (2014). European tourist perspective on destination satisfaction in Jordan's industries. Procedia-Social and Behavioral Sciences, 109, 14161425 .

Ashworth, G. J., Graham, B., \& Tunbridge, J. E. (2007). Pluralizing pasts. Heritage, identity and place in multiculturalsocieties.

Cahyadi, R., \& Gunawijaya, J. (2009). PARIWISATA PUSAKA: Masa Depan Bagi Kita, Alam dan Warisan Budaya Bersama. Jakarta:UNESCO.

Ginting, N., \& Wahid, J. (2015). Exploring identity's aspect of continuity of urban heritage tourism. Procedia-Social and Behavioral Sciences, 202,234-241.

Ginting, N., \& Rahman, N. V. (2016). Preserve Urban Heritage District based on Place Identity. Asian Journal of Environment-Behaviour Studies, $1(1), 67-77$.

Ginting, N., Rahman, N. V., \& Husna, N. (2020, April). The Landmark Aspect of Distinctiveness Toward The Religious Tourism In Langkat District. In IOP Conference Series: Earth and Environmental Science (Vol. 452, No. 1, p. 012055). IOP Publishing.

Huang, D. L., Rosenberg, D. E., Simonovich, S. D., \& Belza, B. (2012). Food access patterns and barriers among midlife and older adults with mobility disabilities. Journal of aging research, 2012.

Hussain,K.A.M.,\&Ujang,N.(2018).IdentificationofLandmarksintheHistoricDistrictof Banda Hilir, Melaka, Malaysia. Asian Journal of Quality of Life, 3(9),99-110.

Lynch, K. (1960). The image of the city (Vol. 11). MIT press. 
Mavoa, S., Witten, K., McCreanor, T., \& O'sullivan, D. (2012). GIS based destination accessibility via public transit and walking in Auckland, New Zealand. Journal of transport geography, 20(1), 15-22.

McCabe, S., \& Stokoe, E. H. (2004). PLACE AND IDENTITY IN TOURISTS'ACCOUNTS. Annals of Tourism Research, 31(3),601-622.

Samsudin, N. A., Rosley, M. S. F., Raja Shahminan, R. N., \& Mohamad, S. (2018). Preserving the Characteristics of Urban Heritage: An insight into the concept of Malaysian Royal Towns. Environment-Behaviour Proceedings Journal, 3(7), 277-283.

Selmanovic, E., Rizvic, S., Harvey, C., Boskovic, D., Hulusic, V., Chahin, M., \& Sljivo, S. (2018). VR Video Storytelling for Intangible Cultural Heritage Preservation.

Shi, J., \& Ying, X. (2008). Accessibility of a destination-based transportation system: a large airport study. Tsinghua Science and Technology, 13(2), 211-219.

Spirou, C., Gardner, S., Spears, M., \& Allegretti, A. (2020). The Sweet Auburn Historic District in Atlanta: Heritage Tourism, Urban Regeneration, and the Civil Rights Movement. In Tourism, Cultural Heritage and Urban Regeneration (pp. 85-96). Springer, Cham.

Staiff, R. (1999). Tourism and Western visual culture. In Australian Tourism and Hospitality Education (CAUTHE) 9th National Research Conference, Adelaide,February.

Timothy, D. J., \& Boyd, S. W. (2003). Heritage tourism. PearsonEducation.

Zakariya, K., Haron, R. C., Yusof, Z. B., \& Ibrahim, I. (2020). Potentials of Technical Tours for Special Interest Tourists in Kuala Lumpur. Environment-Behaviour Proceedings Journal, 5(14), 147-154. 